\title{
Optimum Structural Design of Self-Supported Shelter for Tsunami Evacuation in Padang City
}

\author{
Febrin Anas Ismail ${ }^{1, *}$, Jati Sunaryati $^{1}$, and Deded Eka Sahputra ${ }^{1}$ \\ ${ }^{1}$ Civil Engineering Department, Universitas Andalas, Kampus Limau Manis, Padang
}

\begin{abstract}
A Self-Supported Shelter is a building that has an area about $100 \mathrm{~m}^{2}$ to $1000 \mathrm{~m}^{2}$ designated as a temporary vertical shelter for tsunami evacuation. The Self-Supported Shelter is built and managed by the community. That size of shelter is fit for mosques or mushollas (small Mosques) which is about 700 units spreading in the districts of Padang City. The Self-Supported Shelters are proposed since the number of vertical shelter is very limited at the moment. There are only four vertical shelters available in Padang City which are built by Government with capacity 2000-3000 people. Meanwhile, there is at least 600,000 people of Padang City must be evacuated in case of tsunami. There are four reasons for proposing the mosques or mushollas to be vertical shelters: First, that kind of building are available to small sub-district. Second, the land may be free to be developed. Third, they have an organization chosen by the community. Forth, it is easy to get construction funding for the religion reason. However, the community does not have guidance for developing a shelter for tsunami evacuation. This study is purposing to develop the optimum design of shelter in term of structural analysis. Here, the shelters are categorized into three types base on the area of the mosque or musholla: $10 \mathrm{~m} \times 10 \mathrm{~m}, 20 \mathrm{~m} \times 20 \mathrm{~m}$ and $30 \mathrm{~m} \times 30 \mathrm{~m}$. Frame Structural Systems are used for the main structure of the building with or without the bracing system are involved. The optimum structural design is taken based on the strongest structure to restrain the applied loads. The soil-structure interaction analysis is also considered in to get a more reliable design. The results of the study may be used to guide the communities to build a proper shelter in their area
\end{abstract}

\section{Introduction}

West Sumatra was hit by a strong 7.6 magnitude earthquake on September 20, 2009. This earthquake occurred off the coast of Sumatra, about $50 \mathrm{~km}$ northwest of Padang City [1]. The earthquake caused severe damage in several areas in West Sumatra such as Padang Pariaman Regency, Padang City, Pesisir Selatan Regency, Pariaman City, Bukittinggi City, Padang Panjang City Agam Regency, Solok City, and Pasaman Barat Regency [2]

. When viewed from the cities that experienced the impact of the earthquake, then for the city of Padang, the echo effect that must be considered in addition to building damage is the impact of the tsunami. This is because the city of Padang is directly adjacent to the Indonesian Ocean, and the largest megetrust center is in the Mentawai Islands which is directly facing the city of Padang

To that end, the government of West Sumatra and the city of Padang, through the National Disaster Management Agency, are trying to build shelters that could become the main alternative for people to save themselves in the event of an earthquake and tsunami. The shelter placement is sought to be easily affordable for the community to evacuate themselves. But sometimes in the evacuation area the making of shelters is punished by land limitations. For this reason, a careful study needs to be done so that the shelter that is built can be in optimum condition for its use

In this study, a study of three sizes of shelter buildings was conducted. The study was conducted on the response of the structure and construction costs of the three measures

\subsection{Shelter structure design criteria}

Basically, the easiest structure in calculation and implementation is a structure with a Special Moment Bearer Frame System (SRPMK). This system can be modified to be more efficient in accepting external loads. External loads which are horizontal and dynamic sometimes force the structure to be strengthened. This is one reason, SRPMK sometimes has to be designed into a structure using bressing.

Bresing is one of the earthquake resistant structural systems in building construction. Generally placed crossed (diagonally) with varied configurations on the inside of the portal structure. The use of bracing adds to the rigidity of a portal efficiently, because diagonal mounting causes the braking rod to retain only axial forces when serving horizontal shear forces (Smith and Coull, 1991) [3].

\footnotetext{
* Corresponding author: febrin@eng.unand.ac.id
} 
The results of Kalibhat et al (2014) showed that displacement and base shear values on the structure capacity curve will produce a hysteritic curve of the inverted $\mathrm{V}$ type requiring wider than the type " $\mathrm{X}$ " bresing. This study analyzes the structure of various forms of concentric displays that are placed at an angle to the plan of the structure with the aim of not being related to architectural components [4]

Nugroho (2018) analyzes the dynamic response of structures in open portals, portals with "V" bracing and portals with diagonal bracing. Based on the analysis conducted on a 4-story reinforced concrete building, it can be concluded that the addition of bracing on the portal structure can reduce the displacement value. Interchanges between floors that occur still meet the required limits. The value of shear forces that occur can be reduced by adding bresing to the portal structure [5] Aryandi, et al (2017) conducted an analysis of the effect of bracing on the seismic performance of reinforced concrete structures. The results showed that X-shaped bracing has the most rigid properties for UX and UY directions with a ratio of 0.34 and 0.41 of type 1 structure, while bentuk type bracing has the most ductile properties among other branding forms. Ground floor shear capacity capacity has the greatest increase for Xshaped bracing with a ratio of 1.63 for UX and UY directions. Performance levels for types 1 and 2 structures are immediate occupancy based on the ATC40 method [6]

Andrini, et al (2016) analyzed the performance of reinforced concrete structures with variations in the placement of inverted V. bracing. From the results of the analysis, it was concluded that reinforcement with bracing was able to reduce the displacement value and ductility of reinforced concrete structures. The use of bracing reduces the period of the building structure, reducing the value of displacement in the $\mathrm{X}$ direction by $1.328 \%-42.013 \%$, the Y direction by $10.00 \%-39.394 \%$. Ductility value of the structure has increased compared to buildings without bracing reinforcement. Performance level of the building structure is safe. This shows that the use of bracing can increase the stiffness, strength and stability of the structure [7]

\section{Shelter Modeling}

In order to obtain the optimum prototype shelter, 3 shelter sizes are chosen namely, $10 \times 10 \mathrm{~m} 2$ (type 1 shelter), $20 \times 20 \mathrm{~m} 2$ (type 2 shelter) and $30 \times 30 \mathrm{~m} 2$ (type 3 shelter). The axle spacing of the third column is the same type of shelter which is $5 \mathrm{~m}$. Each type of shelter will be modeled as SRPMK (type A) and structure with type V type (type B). For more details, the types of shelter can be seen in the following figure

The soil data used is as the data in [8] is a soil data with moderate conditions where the modulus of elasticity $\mathrm{E}$ is $265,300 \mathrm{kN} / \mathrm{m} 2$, Poisson's ratio, $\mu 0.3$, qu $150 \mathrm{kN} / \mathrm{m} 2$ and density $\gamma 16 \mathrm{kN} / \mathrm{m} 2$

The regulations used in designing shelters are SNI 2847-2013 concerning Requirements for structural concrete for buildings [9], SNI 1727-2013 concerning minimum loading for building design refers to [10]. SNI 1726-2012 concerning Procedures for planning earthquake resistance for building and non-building structures. Bandung [11] and tsunami loading refer to FEMA P - 646 [12].

\subsection{Type 1 shelter}

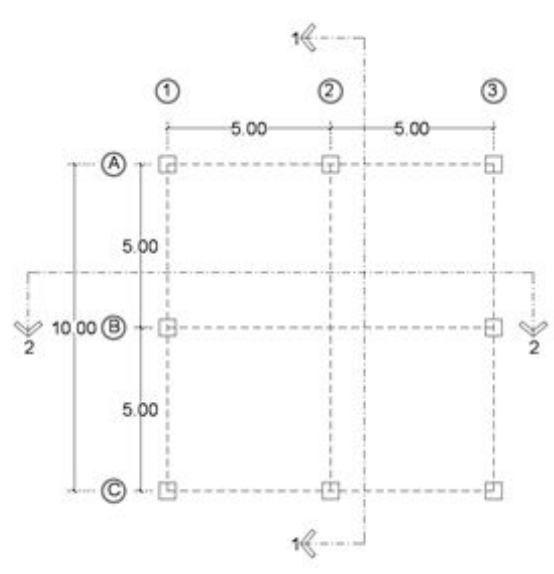

Fig. 1 Type 1 shelter plan, floor plan sixe 10 x $10 \mathrm{~m} 2$

Type 1 shelters are $10 \times 10 \mathrm{~m} 2$ floor plans. The distance between columns is $5 \mathrm{~m}$ (Fig. 1). These shelters have two types namely shelters with the SRPMK system called shelters type 1A (Fig. 2a) and shelters with type V steel bracing are called shelters type 1B (Fig. 2b)

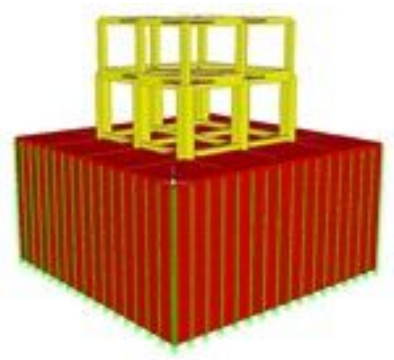

(a)

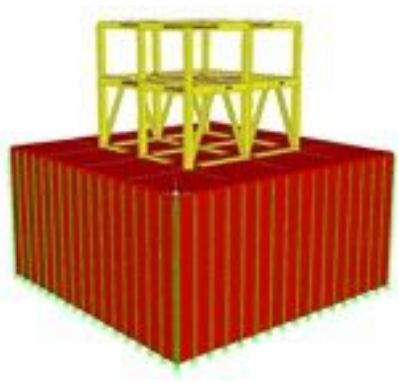

(b)

Fig. 2(a) Type 1A shelter, SRPMK (b) Type 1B shelter, the structure of the moment resisting frame with bracing $\mathrm{V}$ 


\subsection{Type 2 shelter}

Type 2 shelters are $20 \times 20 \mathrm{~m} 2$ floor plans. The distance between columns is $5 \mathrm{~m}$ (Fig. 3). These shelters have two types namely shelters with the SRPMK system called shelters type 2A (Fig. 4a) and shelters with type V steel bracing are called shelters type 3B (Fig. $4 \mathrm{~b}$ )

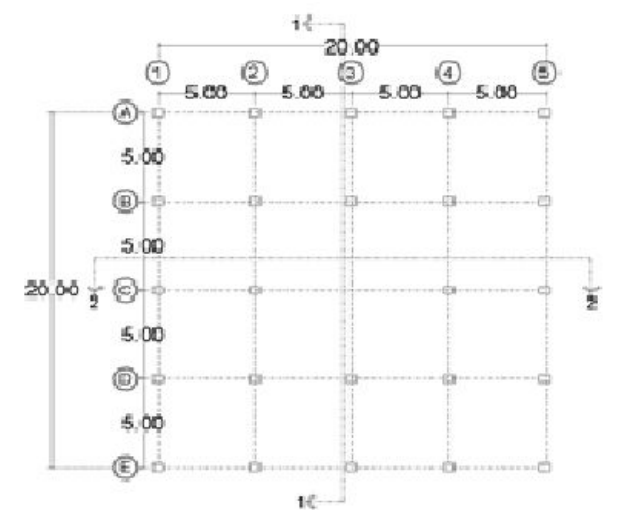

Fig. 3 Type 2 shelter plan, floor plan sixe 20 x 20 m2

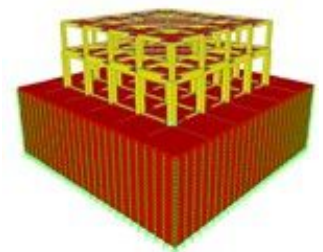

(a)

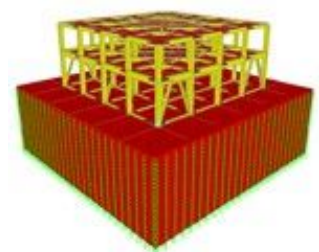

(b)
Fig. 4(a) Type2A shelter, SRPMK (b) Type 2B shelter, the structure of the moment resisting frame with bracing $\mathrm{V}$

\subsection{Shelter tipe 3}

Type 3 shelters are $30 \times 30 \mathrm{~m} 2$ floor plans. The distance between columns is $5 \mathrm{~m}$ (Fig. 5). These shelters have two types namely shelters with the SRPMK system called shelters type 2A (Fig. 6a) and shelters with type V steel bracing are called shelters type 3B (Fig. 6b)

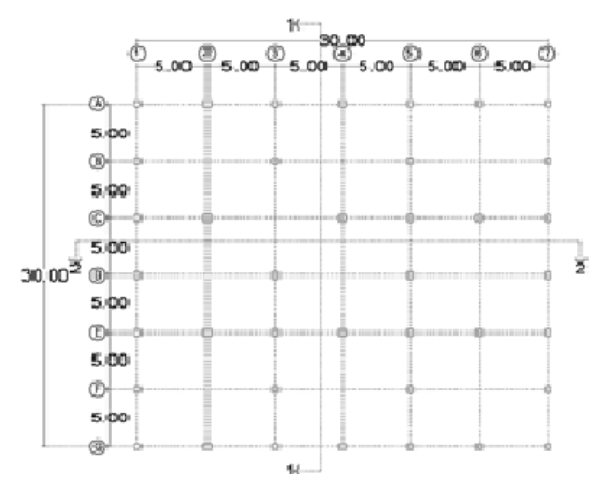

Fig. 5 Type 3 shelter plan, floor plan sixe 30 × 30 m2

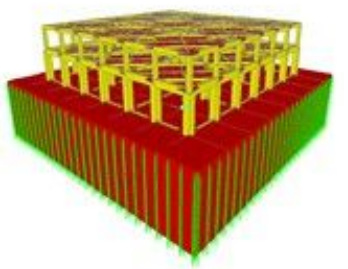

(a)

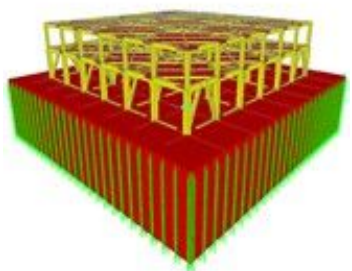

(b)
Fig. 6 (a) Type 3A shelter, SRPMK (b) Type 3B shelter, the structure of the moment resisting frame with bracing $\mathrm{V}$

\section{Discusion}

\subsection{Internal forces}

In general, the Moment Resistant Frame System (SRPM) is a spatial frame system in which structural elements and their joints can bear forces acting through structural responses in the form of flexural, shear and axial responses. Specifically, the special moment bearing frame system (SRPMK) is used for structures in zones with high earthquake intensity.

At SRMPK, the planned portal is in full detail with specific details. A given portal designed as SRPMK is given a plastic joint at both ends of the beam and both ends of the column, the SRPMK portal must also be able to guarantee that the column strength is higher than the beam. A detailed explanation of the SRPMK portal design is found in Article 21.5 and Article 21.6 of SNI 2847: 2013 (Structural concrete requirements for buildings).

Meanwhile. one form of structure that is able to withstand lateral forces due to earthquakes in tall buildings, is the addition of lateral stiffener (bracing) on the skeletal structural elements. This structural system is often called the Bresing Framework System (SRB).

An overview of the structural responses to the SRMPK and SRB shelter prototypes is as follows

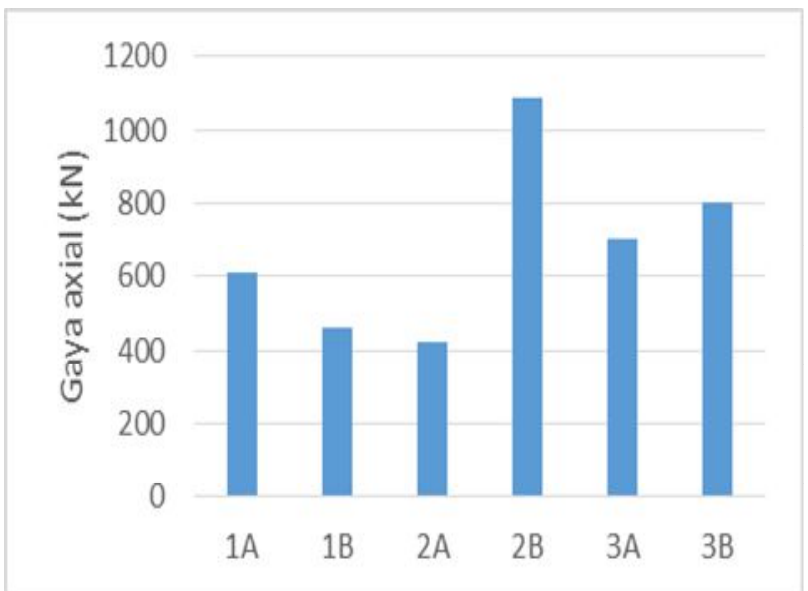

Fig. 7. Axial force that occurs in the column 


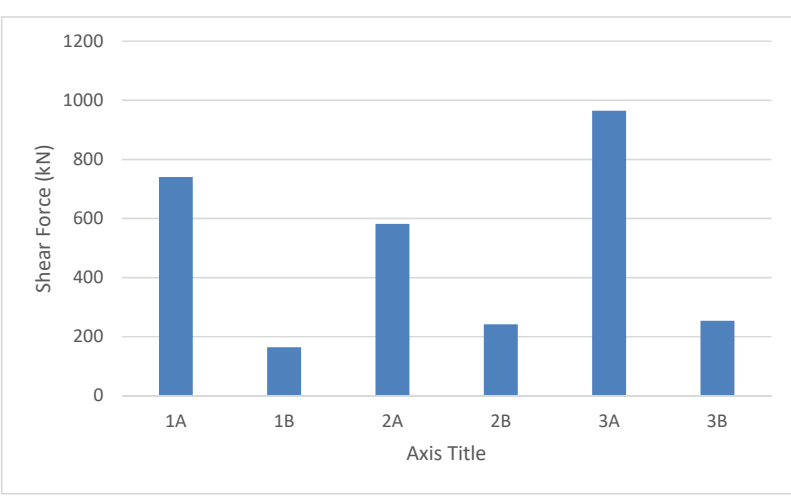

Fig. 8. Shear force that occurs in the column

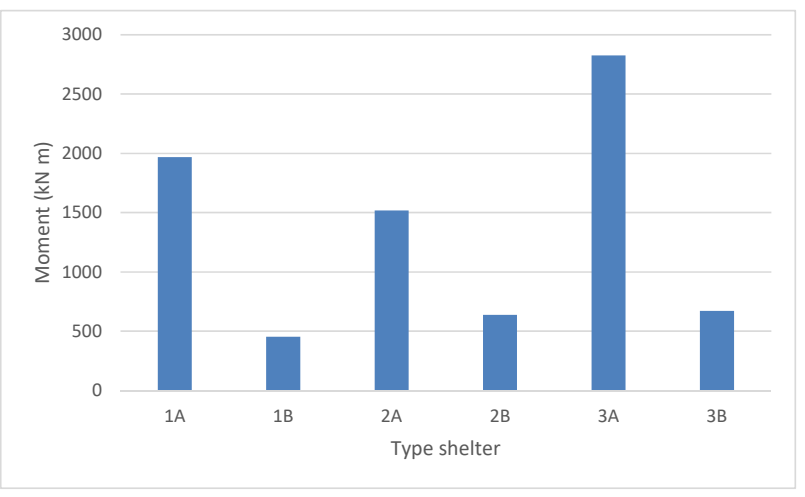

Fig. 9. Moment that occurs in the column

From the graphs of the internal forces, the special moment bearing frame (SRPMK) value of the internal forces that occur is relatively greater, especially the shear forces and moments, due to the large horizontal base shear forces that occur fully borne by the frame structure

\subsection{Interstory drift}

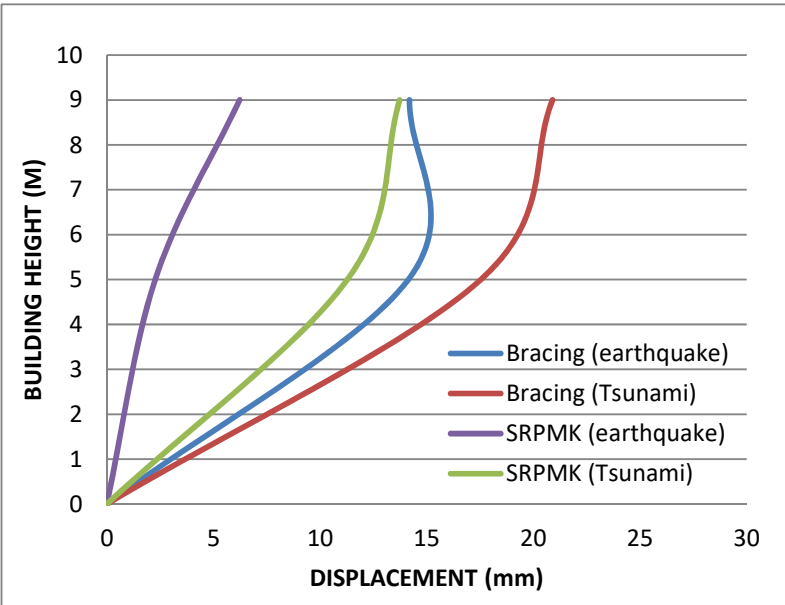

Fig. 10. Story drift that occurs in type 1 shelters due to earthquake and tsunami loads
The influence of the earthquake force and the effect of the tsunami gives different responses to each type of filter. Structural responses in the form of intersections between floors need to be reviewed for each type of structure so that it is observed which effect is dominant on the displacement of the structure. The intersection between floors can be seen in Fig. 10, 11 and 12

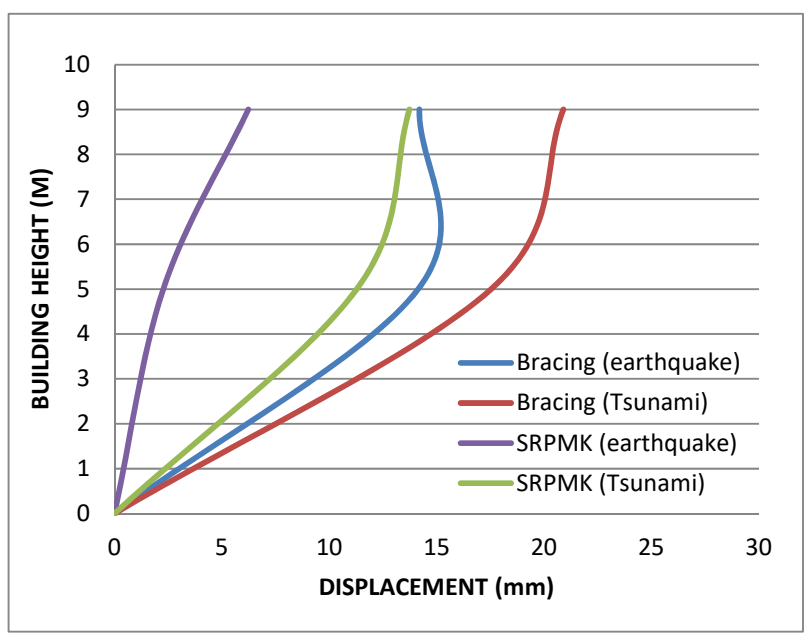

Fig. 11. Story drift that occurs in type 2 shelters due to earthquake and tsunami loads

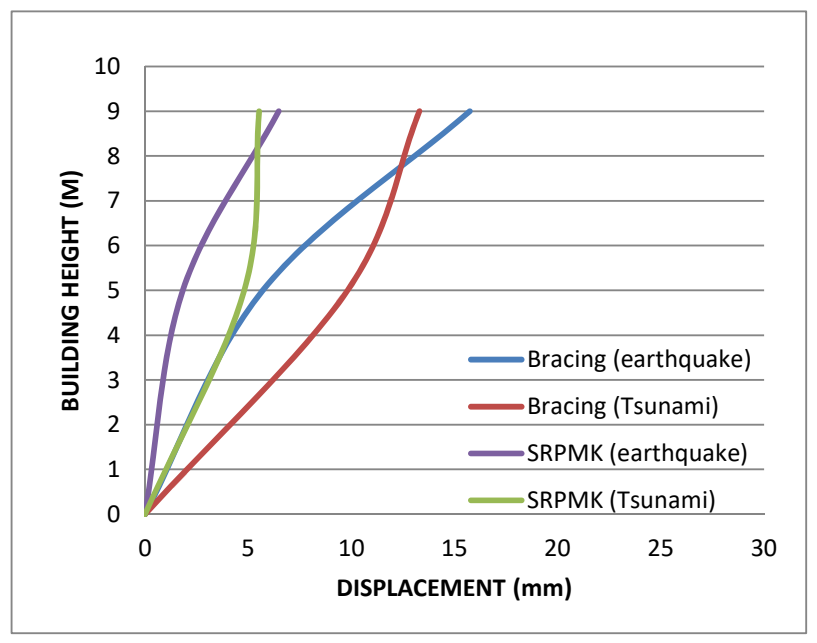

Fig. 11. Story drift that occurs in type 2 shelters due to earthquake and tsunami loads

From the design dimensions of structural elements in each model, it is necessary to control inter-floor deviations due to earthquake and tsunami loads. From the graph shown in Fig. 5. Shows that each type of tsunami load structure is more dominant to contribute the magnitude of the horizontal bottom shear force than the earthquake load 


\section{Conclusion}

From the analysis conducted, to get an effective and efficient structural modeling of strength and cost, the following conclusions can be drawn:

The internal force generated from SRMPK is greater than the structure designed by bressing. This will cause the structural element dimensions designed with SRMPK to be even greater

\section{References}

1. United States Geological Survey. 2009 Oktober 02. M7.6 Southern Sumatra, Indonesia, Earthquake of 30 September (2009)

https://earthquake.usgs.gov/archive/product/poster/200909 30/us/1462223175698/poster.pdf.

2. KOMPAS.COM. 2009 Oktober 04. 289 Warga Padang Pariaman Masih Tertimbun tersedia pada. https://ekonomi.kompas.com/read/2009/10/04/10153373/2 89.warga.padang.pariaman.masih.tertimbun

3. Smith and Coull. Tall Building Structures: Analysis and
Design. New York: John Wiley \& Sons, Inc.(1991)

4. Kalibhat et al. Seismic Performance of Concentric Braced Steel Frames from Pushover Analysis. Manipal: Manipal Institute of Technology (2014)

5. Nugroho, F. Jurnal Momentum, 20 (1): 9-16 (2018)

6. Aryandi, D., Herbudiman, B. Reka Racana Jurnal Online Institut Teknologi Nasional, 3 (1): 1-11. (2017)

7. Andrini, J.R., Sunaryati, J., Thamrin, R. Jurnal Rekayasa Sipil, 12 (2): 32-39 (2016)

8. Febrin Anas Ismail, Abdul Hakam, M Maisaquddus Hape, M Sofian Asmirza. Internl Journl of GEOMATE, Aug, Vol.17, Issue 60, pp.105- 109, (2019)

9. SNI-2847-2013. Persyaratan beton struktural untuk bangunan gedung. Badan Standarisasi Nasional. Bandung. (2013)

10. SNI 1727-2013. Beban minimum untuk perancangan bangunan gedung dan struktur lainya. Badan Standarisasi Nasional. Bandung. (2013)

11. SNI 1726-2012. Tata cara perencanaan ketahan gempa untuk struktur bangunan gedung dan non gedung. Bandung (2012)

12. FEMA P -646. Guidelines for Design of Structures for Vertical Evacuation from Tsunamis, P646, FEMA (2012) 